\title{
Conclusions of the World Clean Energy Conference, Geneva, 4-7 November 1991
}

At the World Clean Energy Conference, held in Geneva from 4 to 7 November 1991, HE Professor Klaus Töpfer, ${ }^{*}$ Minister of Environment, Nature Protection, and Nuclear Safety, Government of Germany, and HE Chaudhry Nisar Ali Khan, Minister for Petroleum and Natural Resources, Government of Pakistan, both agreed that the major responsibility for climate change lay with industrialized countries. Moreover scientific evidence for the unprecedented speed of global warming was confirmed by the Chairman of IPCC (Intergovernmental Panel on Climate Change), Professor Bert Bolin, ${ }^{\dagger}$ of Sweden. Professor Wilfried Bach warned, on behalf of the Enquête Commission of the German Parliament, that corrective measures must be taken more urgently than most nations are willing to recognize.

Authoritative remarks by the Secretary-General of the World Meteorological Organization (WMO), Professor G.O.P. Obasi, ${ }^{\dagger \dagger}$ of Nigeria, confirmed the importance and urgency of taking action towards the production of carbonfree energies. Gustav R. Grob,** President of the Cercle Mondial du Consensus (CMDC), Derek Davies, DirectorGeneral of the World Energy Council, of London, England, and Dr Hermann Scheer, MP, of Bonn, Germany, President of EUROSOLAR, " reviewed realistic implementation measures for effective 'greenhouse' gas reductions, followed by expert presentations about all available solutions of improved or new energy technologies.

The Conference concluded that technical and scientific know-how clearly exists for cleaning up the energy systems of the world and for replacing them with cleaner, safer, and environmentally sustainable, technologies. Moreover, this is compatible with bringing better energy services within the reach of the majority of the world's population. However, what has been lacking until now has been a commitment by industrialized countries to cut down wasteful consumption, limit harmful emissions from existing energy-sources, set performance-standards based on agreed limits, and introduce clean-energy technologies - without further excuses and delaying tactics!

Participating Ministers and experts, widely representing the public and private sectors, welcomed the

*See his 'Main Points in Opening Address', published on pp. 290-2 of this issue. - Ed.

† See his paper published on pp. 297-303 of this issue. - Ed.

†† See his 'Further Statement at Opening of World Clean Energy Conference', published on pp. 293-4 of this issue. - Ed.

** See his 'Background and Objectives of the World Clean Energy Conference', published on page 289 of this issue. - Ed.

\# See pages 357-8 for the 'Substance of [his] Keynote Address to World Clean Energy Conference'. — Ed.
Global Energy Charter, initiated by the World Energy Coalition under the auspices of CMDC (Cercle Mondial du Consensus / World Circle of Consensus), and Minister Nisar Ali Khan expressed the hope of all the members of the World Energy Coalition when he said that

'If [the Charter is] adopted at UNCED, it will bring within reach the aim of sustainable development.'

It was the enthusiasm and commitment of the members of the World Energy Coalition, under the Chairmanship of Dr Hari N. Sharan, $\$$ and others at the Conference, which ensured that the Global Energy Charter became the comprehensive document it turned out to be. Its four objectives, and the eight principles which are aimed at them, were elaborated by subcommittees of the World Energy Coalition during the Conference, and were unanimously approved at the Plenary Session of the World Clean Energy Conference on its final day.

The Conference further came to the conclusion that, when the total life-cycle and external costs of energy generation, distribution, and use, are taken into account, clean, environmentally sustainable, and safe, energy systems are economically competitive. It also noted that a commitment by governments to fund such energy systems, based on this principle and on agreed emission limits, could be negotiated through an international Climate and Energy Convention. A Dedicated Energy Fund, financed from fossil-fuel levies, would facilitate investments in such systems world-wide. Funds should be allocated on an equitable basis, especially to those who are genuinely unable to finance them from their own resources.

Sixteen Ministers, fifty other high-level Government and UN-representatives, and, in addition, a total of some 400 scientists and engineers from sixty-seven countries, endorsed these findings. WMO Secretary-General G.O.P. Obasi, Their Excellencies Professor K. Töpfer, Nisar Ali Khan, Kuupik Kleist, H.K. Kajura, and many other eminent personalities from six continents, agreed that the way forward globally was for the world to adopt equitable solutions to these problems in the interest of future generations, thus ensuring that this planet continues to sustain life more or less as at present.

$$
\begin{aligned}
& \text { GuSTAV R. GROB, President of CMDC } \\
& \text { Secretary-General of the World Clean Energy } \\
& \text { Conference } \\
& \text { Kellerweg } 38 \\
& 8055 \text { Zürich, Switzerland. }
\end{aligned}
$$

$\S$ See his joint account and the Charter on pp. 295- 6 of this

\section{British Nature Conservancy Council: Final Report}

At the time of writing my article on the Reorganization of British Nature Conservation,* the 17th and Final Report of the Nature Conservancy Council (NCC), covering the period 1 April 1990-31 March 1991, was not available. Following the resignation of Sir William Wilkinson, who had been Chairman of the NCC from 1983 to its termination in 1991, this report is now

* Reorganization of British Nature Conservation, by E. Barton Worthington, Environmental Conservation, 18(3), pp. 260-3, 1991. published, signed by Gareth Jones, Chairman of the NCC Residuary Body, with a cover showing a graveyard with beautiful wild flowers in full bloom.

\section{Landmark of Achievement}

This report is a veritable landmark, because the lists of sites and activities which it contains provide the foundations on which the new separate organizations for England, Scotland, and Wales, can now build. Thus the number of National Nature Reserves in Great Britain has 